MŰHELYTANULMÁNYOK DISCUSSION PAPERS

MT-DP - 2007/2

\title{
Evolution on the market of foreign language teaching services in Hungary
}

MIHÁLY LAKI 


\section{Discussion papers \\ MT-DP - 2007/2}

Institute of Economics, Hungarian Academy of Sciences

KTI/IE Discussion Papers are circulated to promote discussion and provoke comments. Any references to discussion papers should clearly state that the paper is preliminary. Materials published in this series may be subject to further publication.

Evolution on the market of foreign language teaching services in Hungary

Mihály Laki, Institute of Economics-HAS, Hungary

laki@econ.core.hu

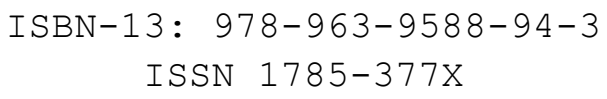




\title{
Evolution on the market of foreign language teaching services in Hungary
}

\author{
Mihály Laki
}

\begin{abstract}
This case study is a part of a research project dealing with the post socialist market evolution. Companies with majority foreign ownership are very rare on the market of foreign language services in Hungary. Import competition is negligible on this market as well. One curious feature of this market is the long term and decisive presence of public education. The demand for language instruction grew rapidly in the last decades of socialism. Competition and presence of private enterprises began in the last year of the socialist system because of the permanent shortage. After the collapse of socialism a large number of new private companies entered this market as well. The demand fell during the transformational recession and rose again in the years of Hungary' EU accession. After this event this market shows more and more signs of saturation.
\end{abstract}

JEL: L11

Keywords

market evolution, regulation of market competition 


\title{
Az idegennyelv-oktatási piac fejlődése Magyarországon
}

\author{
Laki Mihály
}

\section{Összefoglaló}

Az esettanulmány a szocializmus utáni piacfejlődéssel foglalkozó kutatásunk része. Az idegennyelv-oktatási piacon igen kevés külföldi tulajdonú vállalat múködik és az importverseny is elenyésző. E piac különös sajátossága a közoktatás hosszú távú és meghatározó jelenléte is. Az állandó hiány hatására a verseny és a magántulajdonban levő cégek már a szocializmus utolsó évtizedeiben megjelentek ezen a piacon. A szocializmus összeomlása után nagy számban léptek új vállalkozások erre a piacra. A transzformációs visszaesés időszakában a nyelvtanítási szolgáltatások iránti piaci kereslet csökkent, ám az EU csatlakozás hatására ismét növekedett. A csatlakozás után a piac egyre több jelét mutatja a telítődésnek.

JEL kód: L11

Tárgyszavak:

piacfejlődés, piaci verseny szabályozása 
Following the main tendencies of post socialist transitology Hungarian experts of the behavior of companies and of entrepreneurs focused their research activities on the impacts of the changing property rights regime and on the developments of the size and branch structure.

Only a few of them dealt with the symptoms of the post socialist market evolution. ${ }^{1}$ Our research which started in $2004^{2}$ belongs to this trend. In the first stage of the project we presented case studies about the development and change of markets which existed before and after the collapse of the socialist system. ${ }^{3}$ In this article we describe and interpret the development and restructuring of the market of foreign language teaching services in Hungary in the last two decades.

Unfortunately there are only a very few statistical data and quantitative estimations available about the development of this market. Therefore the main sources of information of this article are in dept interviews with owner managers of language schools or studios, with university professors of language-teaching methodology and with representatives of the Association of Language Schools 4 The 25 interviews were made in the years of 2005-2006 and focused on the history of the organization and incentive system of the schools or studios owned an managed by the interviewed. We put detailed questions on the market position of the school as well. We collected additional information from representative surveys on language skills and knowledge of the Hungarian population and from articles and reports published in dailies and weeklies.

The main supplier of foreign language teaching was and is the system of public education managed and/or financed by the central or local governments. There are foreign language courses as integrated parts on the time-tables of the elementary secondary and of high schools. The curriculum at the universities consist language courses as well. The money allocated form the local and central budget to the accounts of the public schools and universities covers (have to cover) the costs of investment and the operation of buildings rooms and laboratories. This money is the source of the wages of teachers and staff as well. The students of the public schools and universities (or their families) are obliged to buy the language and exercise books only.

\footnotetext{
${ }^{1}$ Zsuzsa Kapitány gave a detailed description of the Hungarian car market.(Kapitány 1994) Éva Várhegyi analyzed the changes on the market of banking services. (Várhegyi 2004) Andras Bauer presented an interesting study on the fast development of Hungarian mobile phone market. (Bauer 2003) ) Imre Fertő and Gábor Szabó following the path of the agro-products made interesting statements on the changes of product lines (paths) in post socialist Hungarian agricultural sector. (Fertő-Szabó 2004) Péter Vince analyzed carefully the impacts of privatization on the delivery and supplier contracts of Hungarian companies. (Vince 2003) The book of Éva Voszka is about the relationship between market evolution and market competition in post socialist Hungary. (Voszka 2003)

${ }^{2}$ Financed by the Hungarian Scientific Research Fund

3 Laki (2004), (2005)

4 Association of Language Schools is in Hungarian: Nyelviskolák Szakmai Egyesülete (NYESZE). I shall use this abbreviation in this article.
} 
Different forms of foreign language teaching existed and exist outside the educational system as well:

“- into its regular time table not integrated but by the elementary or secondary school organized forms like language study circles or coaching

- language school

- lessons given by private language teachers" 5

In the last two cases the language teaching is a service for sale on the market. The price of this service is the fee per lesson or per course which have to cover the costs and profit of the supplier.

\section{SOME FEATURES OF THE MARKET OF LANGUAGE TEACHING SERVICES}

We have chosen this market as a subject of research because of its exceptional character. The overwhelming majority of markets of goods and services are dominated by private owned companies as buyers or sellers in post socialist Hungary. As owners of companies the central and local governments play marginal role only. The service we have chosen is an exception in this respect: "The main field of foreign language teaching is the public education."6

Based on a survey which was made in 2004 only $14 \%$ of the questioned attended courses of private language schools in his or her life. The share of those who had lessons at private language teachers was more or less the same: "16\% of the population learned foreign languages in this expensive form." 7 The questioned spent relative short time in these forms of teaching (attending courses measured in hours or weeks only) which refers again to the dominant role of the non-market (public) sector in the foreign language teaching services.

Households moreover companies and institutions are the buyers on this market.

Several registered companies, language teachers with or without licenses are on the supply side of this market. The typical owners of these companies or institutions are private persons or private companies.

We have only estimations on the extent of this market. According to the calculations of NYESZE there are about $800-1200$ professional and registered language schools and studios in Hungary. The chairman of the association estimates that the yearly turnover of this market was 14-20 billion HUF (50-70 million Euro) of the late years ${ }^{8}$

\footnotetext{
${ }^{5}$ Az általánosan (2005) 22.p

${ }^{6}$ Medián (2004) p. 8.

7 Medián (2004) p.12.

${ }^{8}$ Képzős szerkezetek (2006)
} 
Another important characteristic of this market is that a part of the buyers would like to get not only surplus of language skills and knowledge but exam certificates as well. The certificate and the surplus of knowledge are supplementary or twin products (services) therefore we distinguish the market of language teaching services from the market of exams. Several language teaching schools (companies) are present on both of these markets, others supply teaching services only.

\section{PREHISTORY: FOREIGN LANGUAGE TEACHING IN THE SOCIALIST SYSTEM}

After the communist take over, the party and therefore the new administration of education decreed the obligatory teaching of the Russian language in the Hungarian preliminary, secondary and highs schools and at the universities.

In the socialist system only a minority of those who learned Russian was able to use this language in the practice. Those who were employed by the administration of the COMECON or by the headquarters of the Warsaw Pact or worked for state owned foreign trade companies benefited from their knowledge of the Russian language. Those who were employed by big state owned companies which managed cooperation agreements with Soviet counterparts were in the same position.

But the vast majority of the population "could not use its very limited knowledge of Russian because in spite of possessing 'the red passport'9, it was not easy to get the visa (entrance permission) of the Soviet Union. Russian soldiers stationed in Hungary and their families were consciously separated from the population, therefore there were practically no occasion when Hungarians were compelled to exercise their Russian. And Russian was defined as the language of the oppressors of the country which diminished the motivation to learn it by itself as well."10

The fast and forced growth of the number of teachers, the confused and premature methods of teaching of Russian and the overweight of communist ideology and propaganda (with its special and bureaucratic vocabulary) in the texts of language books explain too that "why did not increased the foreign language knowledge of the population in a very long period of time in spite of the huge amount of money and energy invested into the teaching of the Russian language."11

The level of teaching and of books increased gradually in the sixties and seventies but the overwhelming majority of the Hungarians (learning for 8-12 years in the public schools)

\footnotetext{
9 The so called red passport permitted to travel without visa into some socialist countries (Poland, Czechoslovakia, GDR, Bulgaria and Romania) only. When a Hungarian citizen visited Western countries he or she used another so called blue passport (if the permission of the Ministry of Interior was sealed up it.)

${ }^{10}$ Medián (2004) p.5.

${ }^{11}$ Medián (2004) p. 5 .
} 
could not obtain practicable knowledge of Russian. A convincing indicator of the low efficiency of Russian language teaching is that the share of those who learnt Russian is higher but the share of the ones with successful exams is lower than the share of those who learnt English or German languages or have got exam certificates of these two languages. (Table 1 and Table 2)

One other reason for these efficiency differences could have been the more diverse motivation of the students. The knowledge or skill of Western languages ${ }^{12}$ improved remarkably the carrier chances of employed in several sectors of the economy and in the academic-cultural sphere in the last two decades of socialism. The demand for the Russian language did not increased considerably in the meantime. The intensively improving Western connections of the country (OECD membership of Hungary, the country's entry to the IMF) increased the demand for the knowledge of foreign languages and therefore for their teaching as well.

Table 1

\section{Indicators of teaching and knowledge of the Russian language}

\begin{tabular}{|l|c|c|c|}
\hline Age group in 2004 & $\begin{array}{c}\text { The share of those } \\
\text { who learnt Russian in } \\
\text { the elementary } \\
\text { school (\%) }\end{array}$ & $\begin{array}{c}\text { The share of those } \\
\text { who learnt Russian } \\
\text { in the secondary } \\
\text { school (\%) }\end{array}$ & $\begin{array}{c}\text { The share of those who } \\
\text { has middle or upper } \\
\text { level Russian language } \\
\text { exam certificate (\%) }\end{array}$ \\
\hline 25-29 years old & 86 & 13 & 2 \\
\hline 30-34 years old & 96 & 33 & 1 \\
\hline 35-39 years old & 98 & 36 & 3 \\
\hline 40-44 years old & 95 & 51 & 3 \\
\hline
\end{tabular}

Source: Medián (2004) pages 6. and 28.

The department responsible for public education and culture at the Central Committee and the Ministry of Public Education recognized these changes and tendencies. They didn't modify the dominancy of the Russian language but increased the magnitude of teaching of the other languages.

Instead of the traditional Latin the English, German or French became the second available foreign language in several secondary and high schools and at the universities. The structure of teaching moreover of the accumulated knowledge changed only gradually. An article in 1997 described the situation as follows: "the education of the second language ${ }^{13}$ is similar to a reverse pyramid. The language teaching of the elementary schools locates on the

\footnotetext{
${ }^{12}$ English, German, French, Italian

${ }_{13}$ This was the generic term of the modern languages except Russian taught in schools in that time.
} 
top of the pyramid (downstairs in our case) as a curiosity because only $3 \%$ of the students are involved." 14

Table 2

Indicators of teaching and knowledge of the English and German languages

\begin{tabular}{|l|c|c|c|c|c|c|}
\hline $\begin{array}{l}\text { Age } \\
\text { group in } \\
2004\end{array}$ & $\begin{array}{c}\text { The share } \\
\text { of those } \\
\text { who learnt } \\
\text { German in } \\
\text { the } \\
\text { elementary } \\
\text { school (\%) }\end{array}$ & $\begin{array}{c}\text { The share } \\
\text { of those } \\
\text { who learnt } \\
\text { English in } \\
\text { the } \\
\text { elementary } \\
\text { school (\%) }\end{array}$ & $\begin{array}{c}\text { The share of } \\
\text { those who } \\
\text { learnt } \\
\text { German in } \\
\text { the } \\
\text { secondary } \\
\text { school (\%) }\end{array}$ & $\begin{array}{c}\text { The share of } \\
\text { those who } \\
\text { learnt } \\
\text { English in } \\
\text { the } \\
\text { secondary } \\
\text { school (\%) }\end{array}$ & $\begin{array}{c}\text { The share } \\
\text { of those } \\
\text { who have } \\
\text { middle or } \\
\text { upper } \\
\text { level } \\
\text { German } \\
\text { language } \\
\text { exam } \\
\text { certificate } \\
\text { (\%) }\end{array}$ & $\begin{array}{c}\text { The share of } \\
\text { those who } \\
\text { have middle } \\
\text { or uper } \\
\text { level } \\
\text { English } \\
\text { language } \\
\text { exam } \\
\text { certificate } \\
\text { (\%) }\end{array}$ \\
\hline $\begin{array}{l}\text { 25-29 } \\
\text { years } \\
\text { old }\end{array}$ & 19 & 14 & 34 & 33 & 8 & 10 \\
\hline $\begin{array}{l}30-34 \\
\text { years } \\
\text { old }\end{array}$ & 5 & 6 & 18 & 19 & 3 & 7 \\
\hline $\begin{array}{l}35-39 \\
\text { years } \\
\text { old }\end{array}$ & 6 & 4 & 19 & 9 & 4 & 5 \\
\hline $\begin{array}{l}40-44 \\
\text { years } \\
\text { old }\end{array}$ & 7 & 2 & 13 & 10 & 6 & 6 \\
\hline
\end{tabular}

Source: Medián (2004) pages 6. and 28.

\section{EXTRA CURRICULAR TEACHING OF LANGUAGES IN THE SOCIALIST SYSTEM}

The second economy was the main supplier of the extra curricular teaching of foreign languages in the period of socialism. Teachers working for elementary and secondary schools, pensioners with language skills and knowledge earned some extra money by giving lessons illegally.

There were a few registered small cooperatives on this market too but the main supplier of the extra curricular language teaching was the Association for Scientific Education (TIT) in the first economy. ${ }^{15}$ This organization was (similarly to other associations and other

\footnotetext{
14 Dörnyei-Medgyes (1987) p. 31

15 The Association for Scientific Education (Tudományos Ismeretterjesztő Társulat - TIT- in Hungarian) was founded in the first half of the 19th century by Hungarian patriots. The declared aim of the association was to increase the scientific knowledge and technical skills of the Hungarian population.
} 
institutions of the education and culture) controlled and supervised by the communist party organs and by the departments of the state administration responsible for the education of the adult population. The main financial supporter of TIT was the central budget but the association organized and managed several courses lectures or symposiums which were paid by the participants as well.

The after school training became gradually the main task of TIT in the sixties and seventies of the last century. The foreign language teaching began with 103 courses in $1957 .{ }^{16}$ Measured by the number of participants the language teaching became the most popular after school training service of TIT in the meantime. ${ }^{17}$ Because of the fast growing demand the management of TIT established a nationwide network of language schools which consisted 441 courses in 17 counties for 11500 students in 1960. ${ }^{18}$ The number of the language teaching students overcame the number of those who attended the traditional courses of the organization a year later. ${ }^{19}$ The management was strongly interested into this development because the fast increasing income of language teaching services covered a growing part of the costs of other traditional activities of the organization. ${ }^{20}$

A lot of low performing handicapped or ambitious students of the state owned schools and universities were among the participants of the courses of TIT. But the main and fast growing group of those who attended the extra curricular language courses of the association consisted adults who were interested in to enter for official language exam successfully. ${ }^{21}$

Because of its above described inconsistent incentives the market behavior of TIT was controversial. The flexible and consumer friendly management organized more and more courses at companies and governmental organizations. On the other hand TIT was reluctant to adapt new methods of teaching. "It was a lazy big organization. It was not innovative and behaved like the big monopolistic organizations." ${ }^{22}$ - described its attitudes a former teacher of TIT.

\footnotetext{
${ }^{16}$ Karvalits (1989) pp. 229-230

${ }_{17}$ Karvalits (1989) p. 229.

${ }^{18}$ Karvalits (1989)

19 Karvalits (1989) pp 229-230

${ }^{20}$ The subsidies of the central budget stagnated at that time. Karvalits (1989) p. 228.

${ }^{21}$ A departmental order of the minister of education regulated in the state sector (at state owned companies, local governments, ministries, research institutes etc) who were obliged to get official certificate of their language knowledge. The certificate (based on a successful exam) was the necessary condition to get the so called language bonus ( If I remember correctly a single language exam certificate and therefore the bonus increased by 5-8\% of our wages at that time)

22 Part of an interview
} 


\section{PRIVATE LANGUAGE SCHOOLS IN THE SOCIALIST ECONOMY}

The fast growth of the language teaching services of TIT illustrates well the permanent excess demand on this market. Another indicator of the long term shortage was the market entry of newly founded language teaching private ventures.

The Structure Language School was among the first ones. It was established in 1967 by young assistant professors and students of English at the ELTE University in Budapest. It was not a registered company or cooperative (with tax code and registered office) but an informal network based on trust and friendship. The specialty of this school was a new teaching method based on drills and intensive communication.

The activity of the Structure Language School was based on deficiencies of the law: "We have sold our capacities to companies. They made contracts with us or temporarily employed us and we got the honorarium as window cleaners or something like that." 23 The network used this form of market entry when made contracts with the Association of Journalists or with the Patriotic Front. ${ }^{24}$ Based on these contracts they managed several language courses for the members and employees of these organizations and for those outsiders who were informed about and interested in this form and method of teaching. The fee of courses covered the rent of rooms and other costs of teaching. The participants and the receptive organizations were convinced that the network is a language school but the tax office registered and imposed taxes on private persons only.

Because of the reforms of the eighties there were other new entrants on this market. The founders - mainly young language teachers employed by local cultural centers - were not forced to apply the illegal methods based on the deficiencies of the law. The in the eighties introduced and regulated forms of private enterprise and the decreasing political risk of market entry stimulated them to establish profit oriented legal private language schools. The so called small cooperatives and the economic partnerships were the most popular legal forms of private enterprise in that time. ${ }^{25}$

These private language schools adapted or re-discovered several elements of the teaching methods and the organizational system of the Structure Language School.

They opposed the teaching philosophy of TIT as well. "The applied methods and pronunciation were never used at public schools or at TIT before. Our classes were small which was unusual at TIT as well. We have got fantastic video-tapes which was brand new in

\footnotetext{
23 Part of an interview

${ }^{24}$ It was the representative umbrella organization of the allied of the communist party.

25 The authors of a study about the legal private enterprises of the eighties visited 7 newly established private language schools. Five of them were economic partnership and two were cooperatives. (Dörnyei-Medgyes 1987)
} 
Hungary. The interactive method which put the conversation and pronunciation into the center of teaching was adapted first by us in Hungary." 26

These memoirs of the owner manager of a prestigious language school in Budapest coincide with the conclusions of the research of Dörnyei and Medgyes: “An important precondition of high level teaching is that it happens only in small groups (with not more than 10-13 participants) The students of these groups are recruited and selected by tests of knowledge and skills. The final exam and the marks are very important. Those who are unable to fulfill the requirements cannot enter the next stage. Up to date books and tapes are used by these schools. The assortment of reference and handbooks for teachers expands permanently. Video recorders and PC-s are available at several schools as well. There are conscious efforts at these schools to create intimate and trust inspiring atmosphere. These are brand new tendencies in the Hungarian language teaching." ${ }^{27}$

The new private enterprises competed first of all with the schools of TIT. The 1987'report registered image building at the new language schools which indices competition within the new sub-sector as well. Part-time payment, teaching second line languages, special courses, on the European market registered brand names, employment of native language teachers were the most popular methods of the image building. ${ }^{28}$

They competed in spite of the permanent excess demand: "Our school was on the fifth floor and the queue of the applicants ended on the ground floor" - remembered another interview partner. ${ }^{29}$ The owner-manager teachers thought that events like this were symptoms of a temporary and abrupt increase of demand only. They assumed that the excess demand would stimulate the market entry of others (and therefore the consolidation of the market) and they expected the tightening of the economic regulation as well. ${ }^{30}$

According to the memories of the interviewed an additional factor, namely the low costs of market entry increased the number of the start ups as well: "It was extremely easy to start the business. We collected the tuition fees of the class first. This cash flow was enough to buy a tape recorder, to pay the rent of a room and to begin to teach. Practically no accumulated money was needed!" 31

Memoirs like this are a bit misleading. The market entry was relatively cheap for those only who accumulated human capital namely skills and knowledge of foreign language teaching.

\footnotetext{
${ }^{26}$ Part of an interview

${ }_{27}$ Dörnyei-Medgyes (1987) 32. p.

${ }^{28}$ Dörnyei-Medgyes (1987) 32. p.)

29 Part of an interview

30 Dörnyei-Medgyes (1987) 34. p.

${ }^{31}$ Par of an interview (owner manager of a language school in Budapest who was earlier a language teacher at a secondary school financed by the local government)
} 
The language school founders of the eighties faced another serious barrier of the market entry. The lack of managerial skills caused remarkable differences between the (by money) measurable/measured costs and the real investments of the start ups. With other words: they invested a lot of work into their new businesses.

It was a very intensive learning by doing process: "I was a typical maid-of-all-work. First of all we tried to obtain language books but there were les books than enough in Hungary at that time. But there was a network connected to the Budapest Foreign Language Bookshop. We bought up the stocks of language books of this nationwide network and tried to manage the leasing of the books. It was a waste of time. Our teachers were unable to control the distribution and re-collection of the books and to collect the money. We were in a chaotic situation. It became clear that not anyone else but we had to organize the logistics: not only the teacher's time table but the whole location of the courses. However we had no central office no school we had only a few rented classrooms. And we permanently rented new and new classrooms as the number of our students increased."- remembered one of the legendary manager-teachers of these glorious times. ${ }^{32}$

Another barrier of entry was the shortage of professional language teachers. It was an interesting combination of complementary markets: the permanent shortage of teachers on the labor market limited the demand generated extension of the market of language teaching services. The language schools (competing on both markets) were ready and able to pay much higher salaries than the public schools. 33

A lot of language teachers - based on their favorable market position - combined the security of the permanent job at a public school with the high income they earned in the new private sector. Instead of leaving the state sector they had a first job there and a second/part time job at the newly established private language schools.

This market strategy of these teachers was advantageous for the private schools as well. The law limited the number of employed at private companies in the late socialism therefore the system of occasional contracts gave a chance for the schools to employ more people. (And interrupt their employment in seasonal-temporary recessions.) Because of the flexible employment the schools paid less taxes and social security benefits than in the cases of permanent employment.

\footnotetext{
${ }^{32}$ Part of an interview (manager at a foreign trade company earlier teacher-manager of a private language school) $33 \mathrm{We}$ focus here on the competitive elements of this industry. But the new private language schools and their surroundings functioned as a network or subculture of the young language teachers and university students in the eighties as well. This network helped to coordinate the business activities, fastened the learning process and therefore diminished the costs of entry in a lot of cases. But this part of the story is not the topics of our paper.
} 


\section{THE PUBLIC EDUCATION OF FOREIGN LANGUAGES AFTER SOCIALISM}

We have mentioned that the new and old market participants forecasted the slowdown of demand on the market of foreign language teaching services in the second half of the eighties. But the socialist system collapsed in 1989 and unexpected processes started on this market. In the public schools and at the state universities: "The change of the system was equal with the abolition of the compulsory teaching of Russian. The free choice of languages became the rule. The impact of this change was very fast and radical. The number of those who learnt Russian diminished near to zero within the space of two years." 34

Not only the ranking of the languages changed in 1989 but the intentions and programs of the planners of public education transformed permanently as well. The share of the foreign languages increased in the time-tables and curriculums of schools and universities. Moreover "the learning of two foreign languages became compulsory in gymnasiums"35

The governments of the post socialist period modified remarkably the structure and the extension of the language teacher's training. The re-training of the Russian teachers and the enlargement of number of students majoring in Western languages were the main methods they used to improve the performance of the public education on this field. The number of university students of English was 4469 and of German 3073 in the school year of 1993/1994. Two years later the number of students of English was 5759 already and of those who studied German increased to 4739. There was a steady growth of the students of English. Their number was 6428 in the school year of 2001/2002. There were 4552 students of German registered in the same school year. ${ }^{36}$

If we use a quantitative indicator, namely the share of those who learned foreign languages, the results of the structural reforms and therefore the performance of this part of the post socialist educational system are impressive. Among those who leaved the state managed school system before the collapse of the socialist system, with other words among those who were over 40 in 2004 only 2 \% learned English and 7\% German language in the primary school. In the age group of 15-19 years old in 2004 the share of those who learned English was $61 \%$ and $44 \%$ of those, who learned German in the primary school. 37

Similar tendencies were observable in the performance of secondary school attendees. Among those who were over 40 in 2004 only $10 \%$, in the age group of $15-19$ years old $61 \%$ learned English in the secondary school. In the case of the German language the shares were $13 \%$ and $44 \%$ in these age groups. 38

\footnotetext{
34 Medián (2004) 1. p

35 Az általánosan..(2004) 19. p.

${ }^{36}$ Statisztikai Tájékoztató (1994), (1996), (2002)

37 Medián (2004) 6. p.

${ }^{38}$ Median (2004) 6. p.
} 
Another indicator of the foreign language teaching, namely the population's knowledge of languages shows a remarkable development after 1989 as well: "The systemic change of the language teaching" sharply distinguishes the age groups. The vast majority of the younger than 25 years old Hungarians has at last a $A 1$ level ${ }^{39}$ minimal language knowledge while the two third of 40-44 years old ones has practically zero knowledge of languages."40

\section{THE DEMAND ON THE MARKET OF LANGUAGE TEACHING SERVICES AFTER 1989}

There are cases when the growing supply generates additional demand. In our case the fast growth of the language teaching capacities in public schools and universities generated a growing demand on the market of language teaching services as well.

Is the reason for these tendencies that the language teaching capacities of the public sector increased but not as fast as the demand of the population?

The answer is more complicated: the additional demand was produced not only by the market but by the state regulation as well.

Among the market generated factors we mention fist the impacts of the labor market: "The one and a half decade of post socialist transformation and especially the period of the EU accession until 2004 modified remarkably the language learning aspirations of the population. The knowledge of languages became an important factor of success because the sphere of their application increased permanently. The development of the telecommunication and of the internet increased further the spectrum of application which gave an additional impetus to obtain knowledge of foreign languages."41

The privatization of state owned companies enlarged the demand of language knowledge and skills as well.

As a manager-owner of a private language school remembered: "The firm was privatized, or the management got the information that it would happen one year later. In both cases the managers knew exactly that it was a must to learn German or English, otherwise they would have been fired. Therefore we have got a huge amount of orderings to manage language course for these people." 42

The modified state regulation generated demand as well. "It was declared that the officially accepted language exam certificate was a precondition of the diploma. The

\footnotetext{
39 The Common European Framework advised by the Council of Europe distinguishes 6 levels of language knowledge:A1 Breakthrough, A2 Way stage, B1 Threshold, B2 Vantage, C1 Effective operational proficiency, C2 mastery

${ }^{40}$ Medián (2004) 48-49 p.

${ }^{41} \mathrm{Az}$ általánosan...(2005) p. 19.

42 Part of an interview
} 
regulation gave preferences 43 for those who take entrance examinations at universities or has already this certificate. Both elements of the regulation strongly stimulated the learning of foreign languages."44

The intensity and the quality of teaching did not fulfill immediately the new requirements but several families adjusted successfully to the changing conditions. When they realized that in the public school of their child "The seventh English teacher begun the same book again and there was no observable development, they made a decision: let's register him/her into a course of a private language school. And they recognized that 2-3 short language courses were more than equal with 3 years of language teaching at the local school." - remembered a private language school founder of the eighties. 45

The modified family strategies increased the demand: "A huge amount of applicants, mainly from the younger age groups, wanted to learn at private schools. They were secondary school and university students for whom the certificate became one of the necessary conditions of the diploma." 46

\section{THE SUPPLY SIDE AFTER 1989}

The demolition of the administrative barriers of the market economy47 and the fast increase of the demand had two important impacts on the market of language teaching services after 1989:

- The private and semi private companies which were founded in the eighties grew as fast as before.

- Hundreds of new private companies entered the market.

The two processes happened simultaneously, especially in Budapest, where "there were 68 private language schools in the last years of socialism. The system has changed and suddenly 200 new schools entered the market within a year." 48

The newcomers had different origin, background and business strategy.

1. The majority of the new private schools were founded - like in the last two decades of socialism - by highly educated language teachers. There were only a few cases when they had some skills of accounting or book-keeping as well. Usually these business oriented teachers had no experiences of professional management but collected some tacit organizational skills

43 More precisely: plus points.

${ }^{44}$ Az általánosan.. . (2005) p. 19

45 Part of an interview

${ }^{46}$ Part of an interview

47 The modified constitution of Hungary repealed all the laws orders and inner directions which limited or negatively discriminated the private economy. Paragraph 9 abolished the advantages of the so called socialist ownership saying that "in the Republic of Hungary public and private property obtain equal protection."

${ }^{48}$ Part of an interview 
and a remarkable amount of human capital when they were employed as teachers at a public school or at a university and they worked in the second economy in the mine time. Spending a long time in both sectors they accumulated know-how, market information, good-will and business contacts which they invested into the new private enterprises.

These school founder teachers considered themselves mainly as small businessmen. If their businesses grew, they recognized this development as a pressure and not as an indicator of success.

2. Another group of the founders had no practice in teaching but accumulated enough managerial skills and some money to invest into their newly established language schools.

Comparing to the group of teacher-entrepreneurs the business strategy of these investormanagers was different. They considered the growth of business as a factor of efficiency improvement. With other words: their business plans were based on the positive impacts of the economics of scale. „If we are entrepreneurs it is obvious to make plans to extend. And we decided to the latter. We invested into advertising all the money we earned in the previous year. And in 1991 the number of students became 1200 comparing to the 200-250 ones of the previous course-cycles. And this was the point when we had to develop a company because the higher number of students needed a new logistics a new system of information, more teacher and staff." 49

3. The language departments at state universities have two targets after socialism.

- They manage and organize all the "official" language courses which are compulsory for the students and are integral parts of the credit system. Like in the socialism the costs of this activity are covered by the budget of the university.

- It was a new development that language departments get strong incentives to increase the revenues of the university.

To fulfill these two expectations the language departments applied the above described "technology" of the eighties: they combined private activity and state property. They offered extra language courses where the participants (mainly students of the university) paid for this service. "The departments became 'quasi language schools' - described this delicate situation a head of a language department.50

The language departments are obliged to pay a definite part of this income to the budget of the university. This income-sharing is a disadvantage in the market competition, but they

49 Part of an interview

50 Part of an interview 
have sophisticated methods to counterbalance it. For example the language departments manage these courses in university buildings where the rent of classrooms is reasonable and the location is very comfortable for the students. Moreover the teachers of the official courses are employed by the university but the same teachers working for the extra courses are subcontractors (authorized private entrepreneurs) of the language department. The outcome of this double character of the same person is very advantageous for the departments because they pay tuition fee without social insurance.

4. The above described 3 types of private enterprises planned long term survival and/or development. But the fast and permanent growth of the demand provoked the market entry of occasional language course organizer ventures as well. "There is a guy sitting in a flat and manages courses by phone with teachers who he never meet before and in buildings or rooms which he never visited. He has no professional skills to evaluate the process. It is called language school but it is a one-person venture which solicits the bribe and transfer, the rest of the money to the teachers whom he found in advertisements of daily newspapers." summarized one of our interview partners the functioning of these businesses. ${ }^{51}$

5. The several hundred new private language schools destroyed the nearly monopolistic market position of TIT. The number of its students diminished, the vast majority of teachers found a new workplace and the network of TIT language schools collapsed. Instead of competing on the language teaching services some local TIT organizations entered new markers. (Several TIT organizations manage successfully the teaching of traffic regulations for example.)

\section{THE COSTS OF MARKET ENTRY}

Not only the deregulation, the fast and steady growth of demand but the low costs of start ups explain the radical changes on the supply side (the fast increase of the players on this market). Those who accumulated enough human capital were able to start a language teaching business with a relatively small amount of money after the collapse of socialism as well. Based on the calculations of our interview partners we estimate that about 50000 HUF (180-200 Euro) was enough to start a private language school in the first years of post socialist transtition.

As one of them remembered:

"We haven't any classroom. A desk in our friend's flat of was the only thing we owned. That was the start of our language school. We had our own office a few months later. We rented classrooms in a public school. There was a room for registration in another school. It

${ }^{11}$ Part of an interview 
was a typical desk-business. The cost of entry was extremely low in that time." ${ }^{2}$ We have to add that the price of teaching facilities (language books, cassettes, drill-books) the rent of the rooms did not increased remarkably in the first years of post socialist transition.

The most important factors of this business remained - as before the change of the system - the skilled language teachers. Their costs definitely influence the market competitiveness of a language school. A popular method of cost reducing was when the school contracted with young teachers, PhD or MA students. There are schools where 60$70 \%$ of the teachers have no university degree until now. This under-educated working force is cheaper when the contracts are illegal and therefore the school doesn't pay taxes and social security benefits.

We have no measurable information about the occurrence of the illegal contracts. But it is very likely that in the eighties discovered flexible organizational forms were applied in a lot of cases. The majority of language teachers who have occasional or long term contracts with private schools kept their job in the public education after the change of the system as well. The subcontracting was as advantageous for the partners as 10 years before. The schools were able to adapt quickly to the market conditions: if the demand fall they suspended a part of the contracts. In the cases of growing demand the school increased the work intensity. The number of teachers did not but the number of students of the course increased therefore the unit costs of the whole process diminished.

\section{DIFFERENT COMPETITIVE STRATEGIES}

The main tool of competition on this market remained the price more exactly the lecture fee of a student/hour. The price calculation is based on a very simple method. The managerowners compare the registered or estimated costs (including the wages of teachers the costs of rent taxes social security) and the expected incomes. The most doubtful factor of the profit-estimation and therefore of the pricing is the number of registered. Based on this cost benefit analysis the management defines the minimal number of student of a profitable course. If the number of registered students is less than the calculated minimum the school offer another course or send away the applicants.

Our interviews show that the fees offered by the schools differ remarkably for a long time not only on the national market but on local markets (in the same town for example) as well. This information coincides with the content analysis of the collected advertisements and other documents as well.

${ }^{2}$ Part of an interview 
We may interpret these differences of pricing that the private language schools had different time horizon and market strategy and therefore used not only different cost reducing methods but their competitive behavior was different as well.

1. The schools which were funded by language teachers (especially those which entered the market in the eighties) were not forced to employ unskilled teachers in the period of the fast market-extension (in 1990-1993). Their most important form of advertisement was the mouth to mouth method. The references of their former students were more efficient than prospectuses and handbills distributed on the streets or advertisements in newspapers or in the local radio stations.

2. The growth oriented schools floated by manager-investors were less quality oriented concerning the teacher's skills and reputation. They did not accumulated students in the informal economy or in the public schools. These schools tried to counterbalance these disadvantages with price reducing or with aggressive advertising campaigns.

\section{THE IMPACTS OF THE SLOW DOWN OF DEMAND IN THE MID 90'TIES}

The fast growing inflation and unemployment the slow down of the economic growth and the stabilization program of the government in 1995 diminished the demand of the language teaching services: "The demand was hindered the consumption of our services was postponed. It was observable first on the company level, such changes are the fastest at companies. It was terribly unpleasant for the schools. And when similar tendencies occurred - not so radically and only for a few months - at the households it was enough to bankrupt a part of the schools." - remembered one of our interview partners53. Not only the fall of demand and the postponed consuming of the language teaching services but the reregulation namely the administrative or voluntary increase of the barriers of market entry caused the diminishing of the market players.

1. The simplest response to this market situation was the going out of the market. Based on the estimations of our interview partners from the 200 private language schools in Budapest only 40-50 remained on the market in the second half of the 90's. Mainly the language course organizer ventures bankrupted or leaved the market.

2. A part of the owner managers recognized the lack of regulation of the market entry and the competition already in the first years of transition. „It was easier to start a hamburger buffet than a language school. The former needed a permission of the National Health Service

53 Part of an interview 
at least." - characterized the circumstances of the first years of transition one of our interview partners. 54

A part of these owner-managers - mainly those who established the first private language schools in the eighties - preferred the collective action of the suppliers and established the Association of Language Schools, Hungary (NYESZE) in 1991. The basic aim of the founders was the protection of quality. „The association's aim is "to provide clear and transparent information to costumers about services of the member schools." 55 Students of the "Qualified and Provides Schools" registered and regularly inspected ${ }^{6}$ by the NYESZE could be sure that these schools would provide

“- high level and efficient teaching,

- skilled teachers,

- correct and exact information about the courses

- civilized conditions of learning

- $\quad$ up to date equipments" ${ }^{57}$

The association not only informs the public but controls the quality and supports the interests of its members. It delivers information about the market conditions and about the current state of regulation, helps the retraining of teachers and coordinates the rules of business behavior as well.

It is important to note that this system of quality control was voluntarily established and accepted by the member schools. Similar to other cases $5^{8}$ the institutionalizing of the voluntary coordination and interest representation contributed to the stabilization and cleaning of the market.

\section{GOVERNMENT GENERATED RECOVERY IN 1997-2001}

Because of the economic recovery of 1997-2001 and of the EU accession process the demand of language teaching services grew again in the last years of the 90's. The additional demand was generated mainly by the government in this period. The central budget and the EU Phare program financed the procurement of language teaching services.

The scale and the conditions of contracts were different on this market niche than on the traditional part of the market. "It was a remarkable performance earlier if a language school

\footnotetext{
54 Part of an interview

$55 \mathrm{http}: / /$ www-ecml.at/html./Quality/english/continuum/external_quality_assurance/nyesze

${ }_{56}$ More details are availabe in the Accreditation Handbook of NYESZE or on the website http://www.ecml.at/html./quality/english/continuum/external_quality_assurance/nyesze

57 http://www.nyelviskola.hu

${ }^{5}$ Laki (2005), (2005a)
} 
served 20000 lectures in a year. Since 1998 unbelievable magnitudes were observable on this market. There were contracts about 50-8000o lectures in a year. The fast and professional construction of these new and big teaching structures was well paid in that time."59

There was not too much information available about the processes on the supply side in this period of recovery. A part of the interview partners remembered that a part of the course organizers came back to the market and some of the growth oriented manager-investors owned companies became language course organizer as well.

\section{SYMPTOMS OF OVERSUPPLY AFTER 2002}

The growth of language teaching services slowed down again after the successful accession of Hungary in 2002. The tendency was similar but the reasons were different on the main sub markets.

The procurements remained the most important source of income at several schools but the budget expenditures for this purpose grew much slower after than before 2002.

The business sector looked a bit promising for the schools because in 2001 "more than a half (54\%) of those who has a language demanding job could not fulfill the language knowledge requirements of the company" 6o Moreover it was difficult to change these employed because "only $26 \%$ of the job applicants fulfilled the expected level of language knowledge at the companies." Therefore "nearly one third of the companies (28.3\%) had no choice but employed people with unsuitable language knowledge.”61

A lot of companies - in spite of the fact that they were not satisfied with the language knowledge of the employed - modified the human resource policy and tried to transfer the expenses of language teaching to the employed. "The majority of companies expects the knowledge and does not support the employee's efforts to learn languages." 62

The growing language knowledge of the Hungarian population made easier to modify the policy the companies as well: "We have to take into consideration that the secondary schools especially the gymnasiums increased the level of teaching in the last 15 years" 63 explained an owner-manager of a language school the new attitude of the business sector.

The growth of the household's demand slowed down as well. The main reason for this turn was that the young age groups became remarkably smaller than before. The number of

\footnotetext{
59 Part of an interview

${ }^{60}$ Major (2002) 177. p

${ }^{61}$ Major (2002) 177. p.

${ }^{62} \mathrm{Az}$ általánosan..(2005) p?

63 Part of an interview
} 
the elementary school graduates was 168300 in 1990 and only 120300 in $2005^{64}$ for example. Another reason for the slow down of the household's demand is that several universities reduced the minimal condition of graduation from the middle to the basic level language exam.

As in earlier periods the under-pricing was the most obvious indicator of the oversupply. There were nearly unknown language schools which permanently offered 50\% lower fees than the respected ones. The quality oriented exclusive schools - mainly the members of NYESZE $^{65}$ - were able to increase the nominal fees (prices) but the rate of this price increase was less than the rate of inflation after 2002. But the main tendency is the absolute fall of fees. "In the case of courses which are organized at companies the average fee is $20-40 \%$ less in 2005 than it was in 2000-2001."66

The most intensive price competition occurred on the market of procurements. Not only the general oversupply but the special interests of the buyers pressed down the fees: "The lowest price as the only criteria of selection proceedings became nearly dominant. It is a signal of the somehow chaotic relationships on the market of language teaching services that this process generated a price down impact in the last 3 years the result of which is that schools won some procurement tenders with 30-40\% lower fees in 2005 than in $1999 .{ }^{67}$

\section{HOW TO SURVIVE OR TO DEVELOP?}

All of the market players suffer from the impacts of the oversupply but the growth oriented language schools are in a real danger. A part of these companies is not willing or unable to participate in the price competition. Instead of down-pricing they improve the level of teaching or introduce additional services. We collected the most popular methods of adaptation and competition in this group of schools which are the following:

\section{Improvement of the physical and mental conditions of learning.}

The majority of schools rent rooms in office buildings flats or schools which were not designed for teaching. Buy or rent complete school-like service houses where the lecture rooms, laboratories, offices, the information desk and the relax rooms are in the same space, makes the school more attractive and therefore more competitive on the market.

\footnotetext{
${ }^{64}$ Statistical Pocket Book of oHungary 2005 p. 135

65 The membership of NYESZE increased much slower than its founders expected. There are about 65 registered members of the association which represent not more than $10-15 \%$ of the magnitude of the market.

${ }^{66}$ Part of an interview

${ }^{67} \mathrm{Az}$ általánosan .(2005) 81. p
} 


\section{Entry into new market niches}

Because of the slow down of the growth of demand on the traditional markets, more and more schools offer courses for nursery-school children or junior school pupils. Another type of entry was when language schools moved into the traditional market of the private teachers and offered courses or language lessons for single persons. (For high ranking administrators or top managers for example)

\section{Pupil's assessments and direct marketing}

As we have mentioned before the majority of the students attends schools which are recommended by friends by relatives or by colleagues. A part of the manager-owners were not satisfied with this mood of selection and therefore applied the methods of direct marketing as well. "Based on a method of tele-marketing we are able to contact everybody who is ready to give us some basic information. They are at home and our specialists visit them and give advises based on a little questionnaire. There are questions concerning the level of knowledge about the language exams of the applicant and about the usage of languages. We would like to figure out whether the visited person is ready to learn languages or not. We may come closer to them and may prepare special offers for these people."68

\section{Official language exams in the school}

More and more school manager-owners realized that language exam as a service of the school is an efficient tool of competition because it is more comfortable and secure for the student to pass the exam at the place than in the language exam centers. There are cases when the exam as a service is not profitable but the generated additional income is positive.

\section{Exclusive services}

There are language schools which established (subcontracted) travel agencies or employ travel agents who offer language courses abroad or combinations of tourism and language teaching in mother tongue countries. Only the biggest schools are able to manage this kind of service.

\section{A new service: labor agency}

After the EU accession of Hungary increased the number of those who wanted to get a job in the countries of the Union. But a lot of them is not competitive on this labor market because of the lack of language knowledge. The combination of language teaching and labor agency may increase the market share: of the school. "We consciously founded a center of language

68 Part of an interview 
teaching and labor agency because a great part of the applicants would like to work abroad. And we may offer both services because this is a teaching center as well. We offer jobs for those who learnt English at this school.”69

\section{Translation, publishing and trade of books}

Interpreting, translation, publishing and trade of books may produce additional incomes and mobilize the seasonally free capacities of skilled teachers and therefore help to keep them in the staff of the school. "The co-owner of our publishing house is a German publishing company. We translate a lot of German books. The German teachers have less and less work. When they haven't courses they translate books."70

\section{Mergers and networks}

The dominant participants of the market competition going to build up nation vide networks of schools. "Instead of open new schools they try to involve the existing ones into market coalitions. They combine the promised advantages of coordinated marketing and of the market share's increase with the more or less hidden intimidation." - informed us one of the interviewed about this new development. ${ }^{11}$

\section{CONCLUSIONS}

1. It is very complicated to measure moreover to estimate the output of the language teaching service. Based on our field research we may conclude that the demand for private language teaching services increased very fast in the last decades of socialism and in the first years of the post socialist transition in Hungary. The demand diminished temporarily in the period of the stabilization program of 1995 which was followed by a recovery generated mainly be the EU accession of the country. Since 2002 the growth of the demand of language teaching services slowed down again.

2. We have documented in this paper that the ideology dependent cultural policy of the communist regime gave absolute priority to the teaching of the Russian language in public schools and universities for decades. This policy created and reproduced the shortage of labor force with knowledge of Western (German, English) languages. This shortage generated and reproduced the above mentioned permanent excess demand of language teaching

\footnotetext{
69 Part of an interview

70 Part of an interview

${ }^{71}$ Pert of an interview
} 
services. This shortage explains as well why begun the restructuring of the market of language teaching services long before the collapse of the socialism.

3. The intensive and permanent interaction between the public and private sectors of language teaching especially in the last decades of socialism fastened the restructuring of this market. The utilization of the physical and human capital which was accumulated in the public sector (buildings of and teachers employed by the public schools) cheapened the market entry of several new private companies or ventures. These private language schools of the late socialism figured out a new mood of function and management. Innovative language teachers were the founders and the key figures of these quality-oriented and growth-avoiding private businesses. They introduced new and efficient teaching methods and applied flexible conditions of employment. They invested few into advertisements because of the favorable references of their consumers.

4. Contrary to the majority of service and product markets in post socialist Hungary, there are only a few foreign owned companies and the import competition plays a marginal role on the market of language teaching services. Another special feature of this market remained the long term presence and of the public education and therefore the coexistence of the two sectors. The schools and universities financed by the state budget deeply influenced the demand of private language teaching after the socialism as well. Not the ideology based priorities and but other forms of the state's involvement like the regulation of language exams, the procurements and the prescription of the level of language knowledge of public servants are efficient tools of the central and local governments to influence the demand of this service and therefore the business strategy of the private companies involved.

5. The large sector of public education allowed the survival and adaptation of the mixed forms of business after the collapse of socialism. First of all language departments of universities established these semi-private companies. We tried to present in this paper that not only these hybrids but the majority of the private schools adapted the methods and behavior of the entrepreneurs of the late socialism in the emerging market economy as well. But new professional profit and growth oriented companies emerged on this market in the last yeas the strategy of which is based on the organizational marketing and management skills of their owners. 


\section{REFERENCES}

"Az általánosan elérhető nyelvoktató programok elemzése" (The analysis of the transparent language teaching programmes)

A Nyelviskolák Szakmai Egyesületének Tanulmánya

(Experts: Bene Fatime, Dányi Anna Dr. Matheidesz Mária, Rádai Péter, Rozgonyi Zoltán, Sípos Júlia, Sziegelné Terecsik Katalin)

Budapest

Babai Éva, a Nyelviskolák Szakmai Egyesületének elnöke (Éva Babai the chairman of NYESZE) Educatio online journal

http//www.neuman,haz,hu/tei/educatio/1997nyar/reality/baiaeva-hu html

Bauer András: Westel A magyar mobil-kommunikációs piac. (The Hungarian mobiletelecommunication market)

Budapesti vezetőképző Központ 2003 BKAE,,Budapest

Dörnyei Zoltán - Medgyes Péter, "Nyelvoktatás - kisvállalkozásban” (Language teaching as small business) Kritika, 12. sz. (1987): 31-35. oldal

„Europeans and their Languages” (2006) Summary Eurobarometer

Fertő Imre - Szabó Gábor, „Értékesítési csatornák választása a magyar zöldség-gyümölcs szektorban"Közgazdasági Szemle (2004): no 1. 77-89.

Háttéranyag a nyelviskolákról (2005) (Backgrund information about the language schools) Oktatási Minisztérium. (mimeo)

Kapitány Zsuzsa, "Unchanged Seller and Buyer Behaviors in the Hungarian Car Markets" Society and Economy, AULA , (1994) Vol. XVI. No. +. 177-185 pp.

Karvalits László “A Tudományos Ismeretterjesztő Társulat története 1949-1965.” (The History of the TIT 1949-1965)

PhD Thesis (mimeo 1989):)

Képzős szerkezetek Nyelviskola piac (Market of language schools) HVG, Trend, 2006 május 20. 56-60 p.

Laki Mihály "Az ásványvízpiac átalakulása” (The restructuring of the market of mineral water) Közgazdasági Szemle, LI. évf. 12. sz. (2004):1151-1171 oldal.

Laki Mihály "Restructuring of the Hungarian shoe Market after 1989" Development and Finance 2005/1. 78-85.

Laki, Mihály - Szalai, Júlia "The Puzzle of Success: Hungarian Grand Entrepreneurs at the Turn of the Millennium.” Europe-Asia Studies Volume 58. Number 3. (2006): May 317347.

Lányi Kamilla, "Enterprises, Markets, Competitive Situations. An Attempt to describe the environment of enterprises" Institute of Economic and Market Research, Budapest (1980):

Major Éva, “A közoktatás nyelvi vizsgareformjának szakmai, oktatáspolitikai és társadalmi feltételei." (The professional political and social preconditions of the reform of language exam system in the public education) Doktori disszertáció, ELTE Neveléstudományi Doktori Iskola (mimeo 2002)

Medián (2004): “Az idegennyelv-ismeret Magyarországon. Jelentés az országos nyelvtudásfelmérés kvantitatív szakaszáról” (Knowledge of foreign languages In Hungary. Report on the quantitative stage of the nationwide language knowledge survey) 
Statisztikai Tájékoztató (1993/1994) (Statistical Bullletin)

Oktatási Minisztérium

Statisztikai Tájékoztató (1995/1996) (Statistical Bulletin)

Oktatási Minisztérium

Statisztikai Tájékoztató (2001/2002) (Statistical Bulletin) Oktatási Minisztérium

Riba István, "Még nem elégséges. A magyarok nyelvtudásának változása"

(It is not enough. The changing language knowledge of the Hungarians) Heti

Világgazdaság, 2004, május 22. 65.-69. oldal.

"Magyarország háromnegyede nem beszél egyetlen idegen nyelvet sem" (The two thirds of Hungarians does not speak foreign languages) TNS Hungary Sajtóközlemény, 2006 november 17.

Várhegyi Éva, "Bank Competition in Hungary.” Acta Oeconomica Vol 54 (3). (2004):

Vince Péter, "East-West networks and their alignment: industrial networks in Hungary and Slovenia" Technovation No. 23. (2003):

Voszka Éva, Versenyteremtés - alkuval (Competition generated by bargain)

Akadémiai Kiadó, Budapest (2003) 


\section{Discussion Papers published since 2005}

\section{5}

GÁCS János: A lisszaboni folyamat: rejtélyek, elméleti problémák és gyakorlati nehézségek. MT-DP. 2005/1

PÉTERI Gábor: Igazodás a piacgazdaság szabályaihoz és megfelelés a helyi elvárásoknak - A városi polgármesterek értékrendje, 2004. MT-DP. 2005/2

SZALAI Ákos: Adóverseny az iparüzési adóban - Az 5000 fő fölötti települések adópolitikája a 2000-es években. MT-DP. 2005/3

Gábor BÉKÉS - Balázs MURAKÖZY: Firm Behaviour and Public Infrastructure: The Case of Hungary. MT-DP. 2005/4

Gusztav NEMES: The Politics of Rural Development in Europe. MT-DP. 2005/5

Gusztav NEMES: Integrated Rural Development - the Concept and Its Operation. MT-DP. 2005/6

JUHÁSZ Anikó -SERES Antal -STAUDER Márta: A kereskedelmi koncentráció tendenciái MT-DP. 2005/7

Hajnalka TARJÁNI: Estimating some Labour Market Implications of Skill Biased Technology Change and imports in Hungary. MT-DP. 2005/8

L. HALPERN - M.KOREN.- Á. SZEIDL: Import and Productivity. MT-DP. 2005/9

Szabolcs LÓRINCZ: Persistence Effects in a Dynamic Discrete Choice Model - Application to Low-End Computer Servers. MT-DP. 2005/10

Péter VIDA: A Detail-free Mediator and the 3 Player Case. MT-DP. 2005/11

László Á. KÓCZY: The Core Can Be Accessed with a Bounded Number of Blocks. MT-DP. 2005/12

Viktória KOCSIS: Network Asymmetries and Access Pricing in Cellular Telecommunications. MT-DP. 2005/13

István KÓNYA: Economic Development, Exchange Rates, and the Structure of Trade. MTDP. 2005/14

Gábor G. SZABÓ - Krisztina BÁRDOS: Vertical Coordination by Contracts in Agribusiness: An Empirical Research in the Hungarian Dairy Sector MT-DP. 2005/15

Attila AMBRUS: Theories of Coalitional Rationality. MT-DP. 2005/16

Jin-Chuan DUAN - András FÜLÖP: Estimating the Structural Credit Risk Model When Equity Prices Are Contaminated by Trading Noises. MT-DP. 2005/17

Lawrence UREN - Gábor VIRÁG: Wage Inequality in a Burdett-Mortensen World. MT-DP. 2005/18

Berthold HERRENDORF - Ákos VALENTINYI: Which Sectors Make the Poor Countries so Unproductive? MT-DP. 2005/19

János GÁCS: The Macroeconomic Conditions of EU-inspired Employment Policies. MT-DP. 2005/20

CSATÓ Katalin: Egy fiziokrata: Paul-Pierre Le Mercier de la Rivière. MT-DP. 2005/21

2006

Krisztina MOLNÁR - Sergio SANTORO: Optimal Monetary Policy When Agents Are Learning. MT-DP. 2006/1

András SIMONOVITS: Social Security Reform in the US: Lessons from Hungary. MT-DP. 2006/2

Iván MAJOR - Why do (or do not) banks share customer information?. A comparison of mature private credit markets and markets in transition. MT-DP. 2006/3 
Mária LACKÓ: Tax Rates with Corruption: Labour-market Effects. Empirical Cross-country Comparisons on OECD Countries. MT-DP. 2006/4

György MOLNÁR - Zsuzsa KAPITÁNY: Mobility, Uncertainty and Subjective Well-being in Hungary. MT-DP. 2006/5

Rozália PÁL - Roman KOZHAN: Firms' investment under financing constraints. A euro area investigation. MT-DP. 2006/6

Anna IARA: Skill diffusion by temporary migration? Returns to Western European working experience in the EU accession countries. MT-DP. 2006/7

György MOLNÁR - Zsuzsa KAPITÁNY: Uncertainty and the Demand for Redistribution. MT-DP. 2006/8

Péter BENCZÚR - István KÓNYA: Nominal growth of a small open economy. MT-DP. 2006/9

Gábor VIRÁG: Outside offers and bidding costs. MT-DP. 2006/10

Péter CSÓKA - P. Jean-Jacques HERINGS - László Á. KÓCZY: Coherent Measures of Risk from a General Equilibrium Perspective. MT-DP. 2006/11

Norbert MAIER: Common Agency with Moral Hazard and Asymmetrically Informed Principals. MT-DP.2006/12

CSERES-GERGELY Zsombor - CSORBA Gergely: Múkincs vagy múködő tőke? Gondolatok a kutatási célú adatok hozzáférhetőségéről. MT-DP.2006/13

Dr. SERES Antal: Koncentráció a hazai kereskedelemben. MT-DP.2006/14

Balázs ÉGERT: Central Bank Interventions, Communication and Interest Rate Policy in Emerging European Economies. MT-DP.2006/15

Gábor BÉKÉS - Jörn KLEINERT - Farid TOUBAL: Spillovers from Multinationals to Heterogeneous Domestic Firms: Evidence from Hungary. MT-DP.2006/16

2007

Mirco TONIN: Minimum Wage and Tax Evasion: Theory and Evidence. Mt-DP.2007/1

Discussion Papers are available at the website of Institute of Economics Hungarian Academy of Sciences: http://econ.core.hu 